\title{
„Dyskursy Młodych Andragogów”, t. 18, 2017, Wydawnictwo Uniwersytetu Zielonogórskiego, ss. 405.
}

Czasopismo „Dyskursy Młodych Andragogów” stwarza możliwość międzypokoleniowego i międzyśrodowiskowego poznawania się, dzielenia poglądami, wynikami badań i wyrażania różnych stanowisk. W roku 2017 wydano 18. już tom rocznika pod red. Małgorzaty Olejarz, Sylwii Słowińskiej, Emilii Paprzyckiej, Małgorzaty Malec-Rawiński i Edyty Mianowskiej. Każdy z numerów rocznika podzielony jest na części, dostosowane do tematyki artykułów (struktura publikacji nie jest stała). Najnowsze wydanie składa się z następujących części: Dyskurs andragogiczny, Dyskurs poradoznawczy, Dyskurs gerontologiczny, Dyskurs animacji kultury, Dyskurs genderowy. Na 18. tom składa się 28 artykułów naukowych w języku polskim i angielskim.

Część Dyskurs andragogiczny zawiera artykuły dotyczące różnych problemów edukacji dorosłych. Moją uwagę zwrócił w tej części artykuł Jarosława Jendzy pt. Pozycjonowanie studentów w narracjach pracowników naukowo-dydaktycznych uniwersytetu jako kontekst dla refleksji nad dydaktycznq funkcja szkoły wyższej, w którym można zapoznać się z mało optymistycznymi wynikami badań. Wynika z nich m.in., że współcześnie, w dobie parametryzacji pracy naukowej na uniwersytecie, studenci są barierą w rozwoju naukowym swoich nauczycieli. Ciekawy wątek, ostatnio popularny w mediach, podejmuje Katarzyna Narkiewicz w artykule pt. Goście czy najeźdźcy? Edukacyjne aspekty debaty publicznej na temat przyjęcia uchodźców w Polsce. Autorka w swoich badaniach ocenia wpływ toczącej się debaty na kształtowanie postaw dorosłych Polaków wobec uchodźców. Wyniki pokazują, że następuje radykalizacja postaw Polaków wobec przyjmowania Obcych w kraju, rozbudzając w społeczeństwie złe emocje oraz brak zrozumienia dla osób potrzebujących i poszukujących pomocy.

Część Dyskurs poradoznawczy składa się z artykułów dotyczących problematyki poradoznawstwa jako formy instytucjonalnego wsparcia osób do- 
rosłych, znajdujących się w różnych sytuacjach życiowych. W części tej moje zainteresowanie wzbudził tekst Agnieszki Koszałki pt. Coaching jako niedyrektywna forma wsparcia osób dorostych w rozwoju kariery, w którym zaprezentowana została innowacyjna i niedyrektywna forma wspierania kariery osób dorosłych - coaching. Inne spojrzenie na poradoznawstwo przedstawia Maciej Jeż w artykule pt. Ludzie Mocy jako doradcy w kulturze Indian Wielkich Równin Ameryki Pótnocnej, prezentując amerykańskich „medicine-menów” jako odpowiedników kapłanów i jednocześnie doradców podejmujących działania pomocowe na rzecz wspólnoty.

W Dyskursie gerontologicznym przedstawione zostały anglojęzyczne artykuły dotyczące seniorów - ich kariery zawodowej, podejmowania aktywności edukacyjnej (uniwersytety trzeciego wieku), edukacyjnego modelu pracy z nimi oraz różnych aspektów opieki. Podjęta przez autorów problematyka jest ważna z punktu widzenia współczesnego wyzwania dla Polski wzrostu liczby osób starzejących się.

Kolejną częścią rocznika jest Dyskurs animacji kultury. W rozdziale tym zainteresował mnie artykuł pt. Znaczenie koncepcji governance $w$ animowaniu społeczności lokalnej, w którym Dorota Gierszewski konceptualizuje animację jako działanie społeczno-edukacyjne, sprzyjające społeczności lokalnej. Nowoczesne środki animacji (m.in. governance) zachęcają w dobie mediów do aktywności obywatelskiej i współzarządzania życiem społecznym. W tekście Beaty Cyboran pt. Animator na tle mapy „Kultura we wspótczesnej Polsce”. O profesjonalizacji zawodowej animatorów kultury autorka przedstawia koncepcje kształcenia animatorów kultury w Polsce i dylematy wobec miejsca zdobywania uprawnień (mała godzin praktyk na uniwersytetach). Uświadamia również, że jest wiele barier w wykonywaniu tego zawodu, m.in. niedookreślona przestrzeń zawodowa, czy brak umocowania formalno-instytucjonalnego profesji.

Dział Dyskurs genderowy składa się z tekstów o rytuałach w związkach, konstruowaniu w nich intymności, podziale ról w polskich związkach emigrantów we Francji, aspektach życia w kohabitacji kobiet i mężczyzn, dobrowolnej bezdzietności a jakości relacji w małżeństwie, zmianie podejścia do randkowania. Moją uwagę zwróciła publikacja Joanny Wróblewskiej-Skrzek pt. Architektura randki a kryzys matrymonialny, w którym przedstawia zmiany, jakie zaszły w obszarze randkowania. Ukazuje randkę w kontekście miłości romantycznej i współbieżnej oraz ich konsekwencji.

Walorami recenzowanego tomu „Dyskursów Młodych Andragogów” są aktualność podjętej problematyki i wielowątkowość dyskusji. Czaso- 
pismo znacząco rozwija zagadnienia związane z edukacją dorosłych. Prezentuje interesujące artykuły oraz raporty z badań, które cechują się wysokim poziomem merytorycznym i metodologicznym. Jakość rocznika podwyższa obecność anglojęzycznych artykułów naukowych, co stanowi także dodatkową wartość na polskim i międzynarodowym rynku czasopism naukowych.

Mateusz Szafrański 